change this situation.

A document leaked to the Financial Times of London gave details of a working draft of the agreement. The United States would agree to drop its dumping cases, and Japan would try to increase US market share in semiconductors to 20 per cent. To prevent future dumping disagreements, the United States would request

WrrH a self-imposed deadline of Saturday, 26 July for concluding the negotiations, Japanese representatives were no doubt surprised when the US team announced on Friday that negotiations had to stop at 1 p.m. The reason? The Trade Representative's office had scheduled its annual picnic for that day, and not even Washington's current heat wave was going to stop plans for a softball game during the picnic.

immediate consultations between the two governments. These consultations would be limited to 14 days, in contrast to the year it now takes to resolve dumping issues. If dumping is suspected, the Japanese government will encourage its industry to provide documentation for the legitimacy of its sales figures.

Even if an agreement is reached, chip prices in Japan will probably stay comparatively low, and US importers are likely to find "loopholes" - purchasing semifinished goods containing chips or buying chips at Tokyo discount stores. Nevertheless, Japanese companies do appear to be worried by the agreement. They find it blatantly unfair and one-sided, placing Japan at a disadvantage to South Korea, Taiwan and especially to US companies that will have access to Japanese production costs under anti-dumping agreements. Japanese industry sees this agreement as being largely beyond their control, having arisen out of the politically close relationship between President Reagan and Prime Minister Nakasone.

As talks moved into the eleventh hour, both sides seemed intransigent. Three US manufacturers complained formally to the Department of Commerce that Japanese companies were trying to cut last minute deals at bargain prices with US customers before signing an agreement. By 30 July a decision has to be made on the EPROM dumping case, and the next day President Reagan must announce what action he will take in the 301 trade case. As Nature goes to press, it is impossible to say what the likely outcome would be.

The US industry is frustrated by the current negotiations. It believes it has an open and shut case against the Japanese both for dumping and for closing their markets. Hopes for agreement may have given way to a desire for retaliation against Japan for its trade practices. But a comprehensive agreement is still the ultimate goal. At stake could be nothing short of the future of the US semiconductor industry. Joseph Palca \& David Swinbanks

High-technology trade

\title{
Anger over supercomputer veto
}

Ufficials at the British Embassy in Washington hope that they can soon resolve "without major compromise" the difficulties of British academics in obtaining US-manufactured supercomputers. Intensive discussions have been taking place over an issue that last week sparked a debate in the House of Commons.

The trouble began when the University of London Computer Centre found that its purchase of a Cray I supercomputer had been blocked by US government regulations. A condition of sale of the supercomputer is that scientists from Eastern Bloc countries and China must not gain access to the machine. But the centre's director, Richard Field, says that although the scientific standards of work carried out on the machine will be monitored, it is not possible to police all the computer's users to ensure there are no scientists from proscribed countries among them.

What has really enraged British opposition politicians is that the computer the centre wants is second-hand and already in Britain; all that has been requested is its transfer from the Atomic Energy Authority's Harwell laboratory. That the United States can control the movement of a computer inside Britain is described by Liberal Member of Parliament $\mathrm{Mr}$ Paddy Ashdown, who initiated the House of Commons debate, as a "flagrant breach of British sovereignty". And it became clear during the debate that while this may be the first time US controls have hit academics, British high-technology companies have had difficulties with US government regulations for some time. Indeed, Ashdown claims that one British company was effectively driven out of business by US sanctions.

The US regulations come on top of the COCOM agreement that regulates the export of strategically sensitive goods from members of the North Atlantic Treaty Organisation and Japan. British companies that wish to export manufactured goods containing any US component (as do most electronic products) now find themselves having to apply for a licence from both the UK Department of Industry and the US Department of Commerce.

Ashdown's exhortations to take on the United States did not go down well with the government. The official response: from Minister of Information Technology Mr Geoffrey Pattie, was that "if we could compel the United States to withdraw

the problem could be eliminated easily. but we cannot ... and US reaction to a direct and comprehensive challenge cannot be predicted". Rather than accept the opposition view of British Prime Mini- ster Margaret Thatcher's "craven subservience to President Reagan“. Pattie dwelt on the overall advantages to Britain of commercial and scientific links with the United States - plus the new efforts to reduce that dependence by strengthening links with Europe in large-scale development programmes. Problems with the United States have to be dealt with by a "case-by-case" approach. he says.

This view is scarcely welcome to British Embassy officials in Washington who have to do the case-by-cáse negotiations and hope for a more general understanding. An agreement is needed soon if research at the University of London is not to be severely disrupted. The computer should be delivered next month according to the contract, on which a prepayment has already been made. If the computer is not in place by the end of the year. the contract will be void and the computer centre will have to do what it can to seek redress. Any decision will also have a bearing on a contract for delivery of a Cray to the Science and Engineering Research council's Rutherford Appleton Laboratory next year.

Alun Anderson

\section{Science Digest dies Washington}

SCIENCE Digest last week became the latest casualty of the turmoil hitting popular science magazines. Hearst Magazines, its publisher, announced that the September issue of Science Digest will be the last. The subscription list and licensing rights to the name have been bought by Time Inc., publisher of Discover, for an undisclosed sum.

The announcement came as a shock to editorial staff, who have been given a week to clear out their desks. Hearst had been trying unsuccessfully to sell the magazine for several months before finally deciding to cease publication, mainly because of a drastic fall in advertising revenues (see Nature 322. 99; 1986). Hearst expects to retain and reassign about a third of the $\mathbf{2 6}$ Science Digest staff.

Time Inc. also recently bought for $\$ 6$ million the logo and subscription list of Science 86 , the popular science magazine published until last month by the American Association for the Advancement of Science; its readers will be offered Discover instead. Science Digest subscribers will be offered a choice of various Time publications. A spokesman for Time Inc. said that Hearst had already made the decision to cease publication of Science Digest before Time agreed to buy the subscription list: the Science Digest logo is not likely to be used.

Tim Beardsley 